\title{
Proteksi Kombinasi Minyak Wijen dan $\alpha$-tocopherol Terhadap Glomerular Injury Melalui Penghambatan Stres Oksidatif Tikus Hiperkolesterolemia
}

\author{
Dewi Sukmawati ${ }^{*}$ \\ Program Pascasarjana, Universitas Brawijaya, Malang
}

\begin{abstract}
Abstrak
Minyak wijen (MW) kaya akan polyunsaturated fatty acid (PUFA) terutama linoleat yang diketahui dapat menurunkan kadar lipid dalam darah. Namun, salah satu kelemahan PUFA sebagai hipolipidemik adalah cenderung mudah untuk teroksidasi karena struktur ikatan rangkapnya. Vitamin E ( $\alpha$-tocopherol) diketahui dapat melindungi struktur PUFA terhadap oksidasi serta dapat menghambat stres oksidatif. Peningkatan stres oksidatif pada hiperkolesterolemia diduga kuat berperan penting dalam patogenesa glomerular injury. Tujuan penelitian ini untuk membuktikan bahwa penambahan $\alpha$-tocopherol pada minyak wijen mempunyai efek sinergis dalam mencegah glomerular injury melalui penurunan stres oksidatif. Penelitian ini menggunakan Rattus novergicus strain Wistar jantan (200 g) yang dibagi menjadi tujuh kelompok masing - masing 4 ekor, kelompok hiperkolesterol (HK), kelompok ke-2, ke-3 dan ke-4 adalah kelompok HK + MW (dosis masing-masing 0,3; 0,6, dan 1,2 ml), sedangkan kelompok ke-5, ke-6 dan ke-7 adalah kelompok HK + MW (dosis masing - masing 0.3, 0.6 dan $1.2 \mathrm{ml}$ ) $+\alpha$-tochopherol $20 \mathrm{mg}$ ). Pengukuruan kadar kolesterol total, Low Density Lipoprotein (LDL), ureum dan kreatinin darah dilakukan pada minggu ke-10. Aktivitas stres oksidatif jaringan ginjal diukur dari kadar malondialdehide (MDA) menggunakan uji thiobarbituric acid (TBA) dan kadar superoxyde dismutase (SOD) jaringan dengan uji Nitroblue tetrazolium (NBT). Pemeriksaan histologis dilakukan untuk melihat deposit matriks dan jumlah sel mesangial pada glomerulus dengan pengecatan Periodic Acids Schiff (PAS). Hasil penelitian ini menunjukkan adanya perbedaan bermakna penurunan kadar MDA antara kelompok MW dengan MW $+\alpha-$ tocopherol pada dosis $0.3(p=0.000)$ dan $0.6 \mathrm{ml}(\mathrm{p}=0.001)$ yang menunjukkan interaksi sinergistik $\mathrm{MW}+\alpha$-tocopherol serta kecenderungan penurunan kadar SOD. Terdapat dugaan interaksi secara potensiasi dengan penambahan $\alpha$ tocopherol pada minyak wijen terhadap penurunan kadar kolesterol total dan LDL. Gambar histologis glomerular injury menunjukkan bahwa kombinasi $\mathrm{MW}+\alpha$-tocopherol dapat menghambat peningkatan jumlah sel $(p=0.000)$ dan matriks mesangial $(p=0.614)$. Hasil ini menunjukkan bahwa penambahan $\alpha$-tochopherol pada minyak wijen mempunyai efek yang lebih baik dibanding minyak wijen sendiri dalam menghambat glomerular injury melalui penghambatan stres oksidatif di jaringan ginjal secara sinergis.
\end{abstract}

Kata kunci: $\alpha$-tocopherol, glomerular injury, minyak wijen, stres oksidatif.

\section{Abstract}

Sesame oil is rich of polyunsaturated fatty acid (PUFA) especially linoleic acid which is known to reduce lipid content in blood. However, one susceptibility of PUFA as hypolipidemic is it tends to be oxidized because of its double bond structure. Vitamin E ( $\alpha$-tocopherol) was known to protect the structure of PUFA towards oxidation and inhibit oxidative stress. The increase of oxidative stress on hypercholesterolemia is strongly expected to have important role in pathogenesis of glomerular injury. This study aimed to assess the addition of $\alpha$-tocopherol on sesame oil that has the effect of sinergy in inhibiting glomerular injury through the decrease of oxidative stress. We used male Rattus novergicus strain Wistar (BW $200 \mathrm{~g}$ ) in seven groups, 4 rats for each group. The groupss are: hypercholesterol (HC), group 2, 3 and 4 is $\mathrm{HC}+$ sesame oil (Each dose $0.3 ; 0.6$, and $1.2 \mathrm{ml}$, respectively), while group 5,6 and 7 is $\mathrm{HC}+$ sesame oil (Each dose $0.3 ; 0.6$, and $1.2 \mathrm{ml}$, respectively) $+\alpha$-tochopherol $20 \mathrm{mg}$. Total cholesterol, Low Density Lipoprotein $(\mathrm{LDL})$, ureum and creatinine of blood were measured on the $10^{\text {th }}$ week. Oxidative stress activity on the tissues of kidney measured by its malondialdehide (MDA) content with the test of thiobarbituric acid (TBA) and superoxyde dismutase (SOD) of the tissues with Nitroblue tetrazolium (NBT). Histological analysis was conducted to assess the matrix of deposit and the number of mesangial cell in glomerulus by the staining of Periodic Acids Schiff (PAS). The results showed significant diffeerences of the decreased MDA content between the group of sesame oil with the group of Sesame oil $+\alpha$-tocopherol on the dose of $0.3 \mathrm{ml}(p=0.000)$ and $0.6 \mathrm{ml}(p=0.001)$. It implied that the synergic interaction of sesame oil $+\alpha$-tocopherol and the tendency of SOD decrease. We assumed the potential interaction is the addition of $\alpha$-tocopherol on sesame oil decrease the cholesterol and LDL. Histology image of glomerular injury showed the combination of sesame oil $+\alpha$-tocopherol inhibit the increasing of cell number and $(p=0.000)$ and mesangial matrix $(p=0.614)$. It indicates the addition of $\alpha$-tochopherol on sesame oil has better effect than only sesame oil in inhibiting the glomerular injury by inhibit the oxidative stress in kidney tissues sinergically.

Keywords: $\alpha$-tocopherol, glomerular injury, sesame oil, oxidative stress

\footnotetext{
* Alamat korespondensi:

Dewi Sukmawati

Address : Program Pascasarjana, Universitas Brawijaya, Jl. Mayjen Haryono No. 169 Malang 65145
} 


\section{PENDAHULUAN}

Hiperkolesterol merupakan salah satu faktor resiko pada penyakit ginjal kronis selain diabetes dan hipertensi. Studi Kohort prospektif di Boston pada tahun 1982-1996 terhadap 4.483 orang laki-laki sehat menunjukkan bahwa terdapat hubungan yang signifikan antara parameter kolesterol dengan peningkatan kreatinin dan berkurangnya kecepatan filtrasi glomerulus (GFR). Pasien yang mempunyai kadar high density lipoprotein (HDL) rendah $\left(<40 \mathrm{mg} \cdot \mathrm{dl}^{-1}\right)$, kadar kolesterol non-HDL yang meningkat $(\geq$ $196.1 \mathrm{mg} . \mathrm{dl}^{-1}$ ) dan peningkatan rasio kolesterol/ HDL ( $\geq 6.8)$ mempunyai risiko 2 kali lipat untuk terjadinya renal insufficiency [1].

Data rekam medis dari Rumah Sakit Dr. Kariadi Jawa Tengah tahun 1995-1998 menunjukkan bahwa penyakit gagal ginjal kronis menduduki tempat ke-2 (16.6\%) setelah glomerulonephritis kronis (46.6\%). Sedangkan di Amerika, prevalensi End-Stage Renal Disease (ESRD) meningkat 2 kali lipat dalam 10 tahun terakhir [1]. Insiden pasien baru dengan ESRD di Amerika tahun 1998 adalah 85.520. Hal ini menunjukkan rata-rata insiden sebesar 308 kasus per satu juta populasi [2].

Berbagai bentuk penyakit renal yang berkembang menjadi renal failure ditandai oleh proliferasi sel mesangial dan akumulasi matriks mesangial yang nyata, sebagai gambaran dari glomerulosklerosis dan nephropathy [3]. Mekanisme yang mendasari progresifi-tas penyakit renal masih belum jelas. Salah satu faktor yang diduga berperan penting dalam patogenesis penyakit renal kronis adalah stres oksidatif [4]. Penelitian terhadap 37 pasien dengan gagal ginjal kronis (Chronic Renal Failure) menunjukkan bahwa lag time fraksi lipoprotein (sebagai antioksidan marker) untuk teroksidasi adalah lebih lama pada kelompok kontrol pasien sehat dibanding pada pasien dengan insufisiensi renal. Kadar diene conjugates dan $\mathrm{LOOH}$ (sebagai marker lipid peroksidasi) juga lebih tinggi secara bermakna pada pasien dengan insufisiensi renal [5].

Penelitian pada hewan coba mendukung adanya hubungan sebab-akibat antara kadar lipid dan terjadinya glomerular injury yang mengarah pada terjadinya glomerulosklerosis. Bukti tersebut menunjukkan bahwa stres oksidatif merupakan faktor patogenetik untuk terjadinya nephropathy yang diinduksi oleh lipid (lipidinduced nephropathy). Penelitian pada tikus dengan uninephrectomy yang diberi diet tinggi lemak $(40 \%)$, kolesterol (5\%) dan asam kolat
(0.35\%) secara signifikan meningkatkan kapasitas pembentukan radikal bebas yang disertai dengan meningkatnya aktivitas xanthine oxidoreductase (XO) dalam glomerulus secara bermakna. Seiring dengan hal tersebut, juga terjadi peningkatan bermakna terhadap jumlah monosit/makrofag glomerular, densitas sel dan matriks mesangial [3].

Hiperkolesterolemia diduga merupakan faktor resiko yang dapat berdiri sendiri dan memperparah nephropathy yang terjadi dengan menyebabkan glomerular injury melalui produksi kolagen proteoglikan, fibronektin dan Platelet Derived Growth Factor (PDGF). Studi pada model penyakit renal menunjukkan adanya hubungan antara kadar kolesterol dalam sirkulasi dengan glomerular injury, berupa glomerulosklerosis, ekspansi mesangial dan hialinosis. Hiperkolesterolemia juga dapat menyebabkan perubahan hemodinamik, berupa meningkatnya tekanan hidraulik kapiler glomerular, vasokonstriksi renal; baik arteriol aferen dan eferen serta meningkatnya resistensi vaskuler [6].

Hingga saat ini belum terdapat terapi spesifik untuk sebagian besar nephropathy kronik yang berkembang menjadi ESRD, maka tindakan pencegahan berperan penting untuk mengatasi penyakit ini. Identifikasi faktor resiko yang dapat dimodifikasi, yang mengawali terjadinya disfungsi renal merupakan langkah awal yang diperlukan untuk menegakkan strategi pencegahan dan alternatif pemikiran pengobatan terbaru [1].

Berdasarkan hal tersebut, National Cholesterol Education Program, Adult Treatment Panel III (NCEP- ATP III) Mei 2001, menekankan pentingnya terapi nonfarmakologi pada penderita hiperkolesterolemia. Perubahan gaya hidup merupakan salah satu terapi yang dianjurkan, termasuk disini adalah diet. Konsumsi lemak yang dianjurkan adalah dengan mengganti asam lemak jenuh (saturated) dengan asam lemak tak jenuh, baik yang monounsturated maupun polyunsaturated yang terutama terkandung dalam minyak tanaman [7].

Minyak wijen (Sesame oil) merupakan salah satu sumber asam lemak tak jenuh, $85 \%$ asam lemaknya berupa asam lemak tak jenuh, yang bersifat lebih stabil dengan adanya antioksidan alami berupa sesamin [8]. Penelitian ahli gizi menunjukkan bahwa minyak wijen kaya akan asam lemak esensial yaitu linolenat $(0.67 \%)$, linoleat (49.5\%) dan oleat (37.5\%) [9].

Selain itu minyak wijen juga mengandung sejumlah lignan yang mempunyai efek 
hipolipidemik dan juga antioksidan. Sesamin, salah satu lignan dalam minyak wijen mempunyai efek hipolipidemik dengan menurunkan secara bermakna kadar kolesterol dalam serum dan hepar pada tikus yang diberi diet kolesterol $0.5 \%$ selama 4 minggu, melalui hambatan absorbsi kolesterol di intestinal dan menurunkan aktivitas HMG-COA reductase, enzim yang membatasi sintesis kolesterol dalam mikrosom hepar [10]. Sedangkan efek antioksidan ditunjukkan oleh lignan sesamolin, yang secara bermakna menurunkan lipid peroksidasi di ginjal dan hepar [11].

Adanya ikatan rangkap dalam asam lemak tak jenuh (PUFA) menyebabkan strukturnya mudah teroksidasi. Sehingga bila dikonsumsi dalam jumlah banyak dapat meningkatkan proses oksidasinya. Oleh karena itu harus disertai dengan konsumsi antioksidan, yang dapat mencegah terjadinya oksidasi ikatan rangkap. Penggunaan $\alpha$-tocopherol sebagai antioksidan telah diketahui luas. Alpha-tocopherol merupakan antioksidan kuat yang larut dalam lemak dan efektif sebagai antioksidan pemutus rantai yang melindungi lipid unsaturated dari kerusakan radikal bebas [12]. Pemberian $\alpha$-tocopherol 200 $\mathrm{mg} /$ hari selama 6 dan 12 minggu pada tikus diabetes yang diinduksi dengan streptozotocin (STZ) secara signifikan menurunkan konsentrasi malondial-dehyde (MDA) ginjal serta menurunkan ketebalan glomerular basement membrane
(GBM) dibanding kontrol [13]. Sedangkan studi Secondary Prevention with Antioxidant of Cardiovascular disease in End-stage renal disease [14], terhadap 196 pasien hemodialisis dengan penyakit kardiovaskuler yang mendapat $\alpha$ tocopherol 800 IU.hari ${ }^{-1}$ melaporkan adanya penurunan kejadian penyakit kardiovaskuler secara signifikan sebesar 54\% dibanding kontrol [15].

Hingga saat ini masih belum diketahui apakah dengan penambahan $\alpha$-tocopherol pada minyak wijen dapat memberikan efek yang lebih baik daripada minyak wijen sendiri dalam menghambat glomerular injury melalui penghambatan stres oksidatif akibat hiperkolesterolemia.

Untuk itu perlu dilakukan penelitian eksperimental untuk mengetahui efek penam-bahan $\alpha$ tocopherol pada minyak wijen, diban-ding minyak wijen sendiri dalam menghambat glomerular injury melalui penghambatan stres oksidatif.

\section{METODE PENELITIAN}

Penelitian ini menggunakan Rattus novergicus strain Wistar jantan (200 g) yang dibagi menjadi tujuh kelompok masing-masing 4 ekor, kelompok hiperkolesterol (HK), kelompok ke-2, ke-3 dan ke4 adalah kelompok $\mathrm{HK}+\mathrm{MW}$ (dosis masingmasing 0,$3 ; 0,6$, dan 1,2 $\mathrm{ml}$ ), sedangkan kelompok ke-5, ke-6 dan ke-7 adalah kelompok $\mathrm{HK}+\mathrm{MW}$ (dosis masing - masing 0.3, 0.6 dan 1.2 $\mathrm{ml})+\alpha$-tochopherol $20 \mathrm{mg}$ ). Alur penelitian dapat dilihat pada gambar 1.

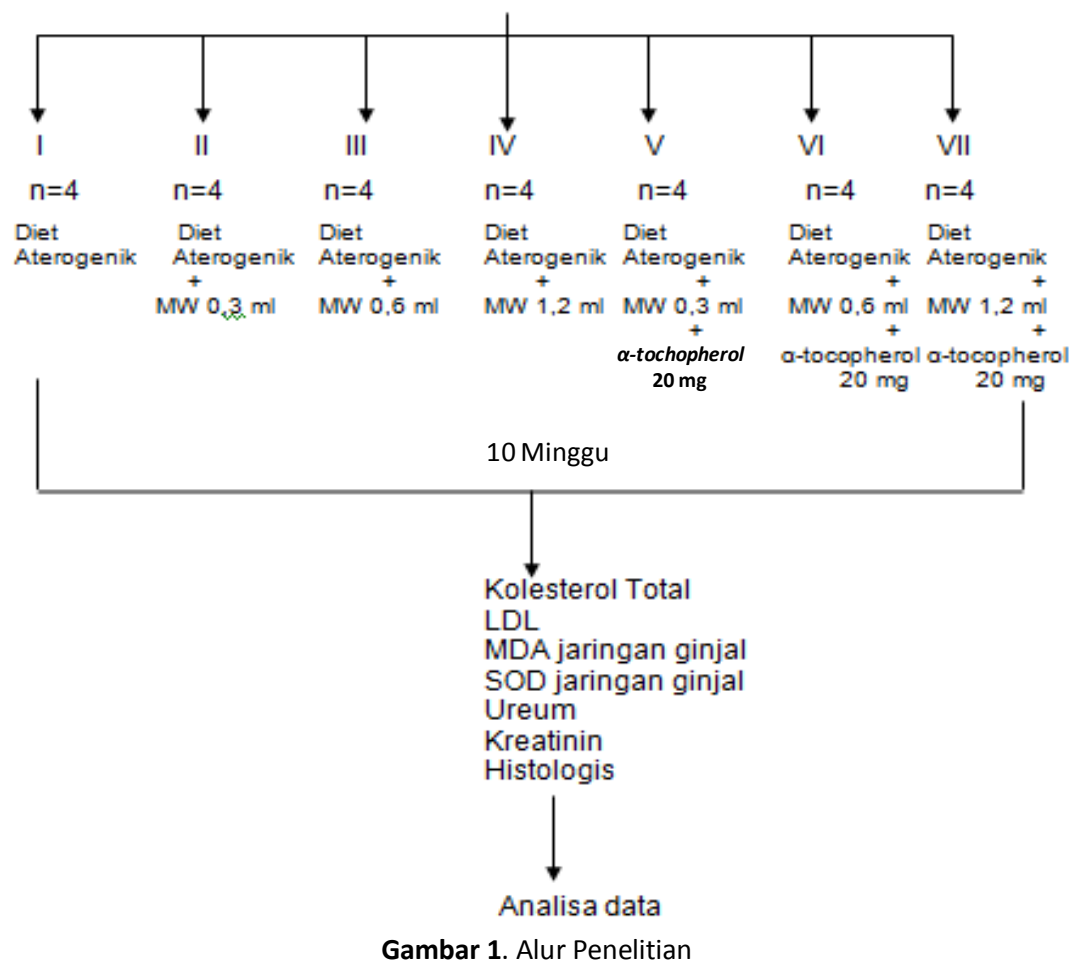

J.Exp. Life Sci. Vol. 3 No. 2, 2013 


\section{Pembuatan Tikus Hiperlipidemia}

Dari studi terdahulu diketahui bahwa kebutuhan makanan tikus dewasa tiap ekor perhari adalah $40 \mathrm{~g}$, yang terdiri dari comfeed $P A R-S$, terigu dan air (pakan standar). Untuk perlakuan hiperkolesterol, digunakan diet atherogenik dari laboratorium biomedik yang sudah terbukti membuat model tikus atherosklerosis dalam waktu 8-10 minggu. Komposisi diet atherogenik merujuk pada studi Ali dan Muliartha [16].

\section{Pengukuran Kadar Kolesterol Serum}

Pengukuran kadar kolesterol total dilakukan pada akhir minggu ke-10. Reagen yang digunakan adalah "Dia Sys Cholesterol FS" yang dibaca dengan menggunakan spektrofotometri dengan panjang gelombang $500 \mathrm{~d} \lambda$.

\section{Prosedur Pengukuran LDL}

LDL diukur secara tidak langsung dengan menggunakan rumus :

$\mathrm{LDL}=$ Kolesterol $-($ Trigliserida $/ 5)-\mathrm{HDL}=\mathrm{mg} \cdot \mathrm{dl}^{-1}$

Catatan: Data trigliserida dan HDL menggu-nakan data bersama dari kelompok penelitian minyak wijen, digunakan oleh peneliti lain

\section{Pemeriksaan Kadar Protein Ginjal}

Sampel jaringan ginjal yang didapat kemudian ditambahkan larutan $\mathrm{NaCl}$ 0,9\% sampai $1 \mathrm{cc}$, kemudian disentrifus dengan kecepatan 3000 rpm selama 10 menit. Supernatan diambil ditambahkan dye dan dibaca menggunakan spektrofotometer dengan panjang gelombang $570 \mathrm{~nm}$ (di laboratorium Biomedik Universitas Brawijaya).

\section{Pemeriksaan SOD Jaringan Ginjal}

Sampel jaringan direaksikan dengan xantin dan xantin oxidase serta KCN 10mM. Kemudian ditambahkan NBT sebagai pewarna, dan dibaca menggunakan spektrofotometer dengan panjang gelombang $580 \mathrm{~nm}$ (di laboratorium Biomedik Universitas Brawijaya).

\section{Pemeriksaan Kadar MDA Jaringan Ginjal}

Digunakan dua sampel jaringan ginjal untuk tes dan kontrol. Masing-masing direaksikan dengan TCA dan $\mathrm{HCl}$ untuk menghentikan reaksi yang berlangsung dan kemudian diwarnai menggunakan NaTHIO. Dibaca menggunakan spektrofotometer dengan panjang gelombang $531 \mathrm{~nm}$ (Laboratorium Biomedik, Universitas Brawijaya).

\section{Pemeriksaan Histologi Ginjal}

Untuk pemeriksaan histologi ginjal dilakukan dengan proses parafin blok serta menggunakan pewarnaan PAS (Periodic Schiff Acid) untuk mewarnai komponen polisakarida dan oligosakarida yang dimiliki sel, dalam hal ini terdapat pada matriks mesangial dan membran dari kapsula Bowman, serta mengamati sel mesangial [17].

\section{Metode pengumpulan data histologis}

Dilakukan pengamatan dan penghitungan terhadap persentase matriks mesangial dan jumlah sel mesangial dengan menggunakan mikroskop binokuler. Pada tiap slide diamati/ ditentukan counting area glomerulus pada daerah korteks ginjal secara acak sebanyak 4 area.

\section{a. Persentase matriks mesangial}

Dengan perbesaran 400x dihitung luas area matriks yang mengisi square mikrometer (1 kotak $=1 \mathrm{x} 1 \mathrm{um})$, kemudian dihitung luas area glomerulus beserta matriksnya. Persentase matriks di peroleh dengan membagi luas area matriks dibagi luas area glomerulus dikalikan dengan 100.

b. Jumlah sel mesangial

Dengan perbesaran 1000x dan munyak emersi dihitung jumlah sel mesangial, yang mempunyai ciri - ciri: sel terbenam dalam matriks mesangial, terletak diantara kapiler dan inti hiperkromatik.

\section{Pemeriksaan kadar ureum}

Bahan yang digunakan adalah Urea kit (Unimate 5 Art. 073685 6) dan serum tikus. Bahan dicampur (Tabel 1) kemudian diinkubasi 15 menit dan dibaca pada photometer dengan panjang gelombang $365 \mathrm{~nm}$.

Tabel 1. Solution untuk pengukuran kadar urenum

\begin{tabular}{ccc}
\hline Bahan & Tes (T) & Kalibrator (K) \\
\hline Working Reagen & $1000 \mathrm{ul}$ & $1000 \mathrm{ul}$ \\
Sampel & $10 \mathrm{ul}$ & -
\end{tabular}

Standar/ kalibrator $\quad$ - $\quad 10 \mathrm{ul}$

Penghitungan hasil $=\underline{\text { Absorbansi } T \text { x }}$ konsentrasi standar Absorbansi $\mathrm{K}$

(Lab. Patologi Klinik Rumah Sakit Saiful Anwar)

\section{Pemeriksaan kadar kreatinin}

Bahan yang digunakan adalah Reagen kreatinin (Unimate 7 Art. 0736678 ) dan serum tikus. Bahan dicampur (Tabel 2) kemudian diinkubasi 15 menit dan dibaca pada photomteer 
dengan panjang gelombang $365 \mathrm{~nm}$. Bahan dicampur kemudian diinkubasi 15 menit dan dibaca pada photometer dengan panjang gelombang $500 \mathrm{~nm}$.

Penghitungan hasil $=$ Absorbansi $\mathrm{T} \times$ konsentrasi standar Absorbansi $K$

(Lab. Patologi Klinik Rumah Sakit Saiful Anwar)

Tabel 2. Solution untuk pengukuran kadar kretinin

\begin{tabular}{lll}
\hline Bahan & Tes (T) & Kalibrator (K) \\
\hline Working Reagen & $1000 \mathrm{ul}$ & $1000 \mathrm{ul}$ \\
Sampel & $100 \mathrm{ul}$ & - \\
Standar/ kalibrator & - & $100 \mathrm{ul}$ \\
\hline
\end{tabular}

\section{Analisis statistik}

Untuk mengetahui apakah penambahan $\alpha$ tocopherol pada minyak wijen berbeda secara bermakna dengan minyak wijen sendiri maka data dari pengukuran kadar kolesterol total, LDL, MDA, SOD, Ureum, Kreatinin, \% matriks mesangial dan jumlah sel mesangial dianalisa serentak dengan MANOVA dan bila ada perbedaan bermakna $(p<0.05)$ dilanjutkan dengan Post Hoc Tukey HSD untuk mengetahui kelompok mana yang berbeda [18]. Selanjutnya dilakukan regresi untuk mengetahui hubungan kausal atau fungsional [19] efek penambahan $\alpha$-tocopherol dibanding minyak wijen sendiri pada tiap dosis. Analisa korelasi dilakukan untuk mengetahui ada-tidaknya hubungan kausal antara parameter stres oksidatif dengan glomerular injury dan seberapa besar hubungan tersebut [18]. Untuk mengetahui perubahan histopatologi pada ginjal maka mula-mula di baca secara deskriptif kemudian di coba dikuantifikasi.

\section{HASIL}

Hasil pengukuran kadar kolesterol total

Berdasarkan hasil penelitian menunjukkan adanya penurunan kadar serum kolesterol total, pada semua kelompok minyak wijen (MW), dengan atau tanpa penambahan $\alpha$-tocopherol. Kelompok MW pada semua dosis $(0.3,0.6$ dan $1.2 \mathrm{ml}$ ) menunjukkan efek menurunkan kadar kolesterol total. Demikian pula dengan kelompok $\mathrm{MW}+\alpha$-tocopherol pada semua dosis $(0.3,0.6$ dan $1.2 \mathrm{ml}$ ) mempunyai efek menurunkan kadar kolesterol (Tabel 3).

Hasil analisis regresi menunjukkan adanya dua persamaan garis linear yang berbeda, antara kelompok minyak wijen saja dengan yang ditambah $\alpha$-tocopherol. Kelompok MW tampak berbentuk linear dan menunjukkan adanya hubungan dosis - efek, yang berarti bahwa penambahan dosis minyak wijen berpengaruh terhadap penurunan kadar kolesterol total. Dosis $0.3 \mathrm{ml}$ menunjukkan penurunan kadar kolesterol yang lebih bermakna daripada dosis 0.6 dan $1.2 \mathrm{ml}$. Pada dosis 0.6 dan $1.2 \mathrm{ml}$ memberikan efek penurunan kadar kolesterol yang sama. Sedangkan untuk kelompok MW + $\alpha$-tocopherol, menunjukkan bentuk linear dan juga terdapat hubungan dosis-efek. Dosis 1.2 $\mathrm{ml}$ menurunkan kadar kolesterol lebih bermakna daripada dosis 0.3 dan $0.6 \mathrm{ml}$. Sedangkan pada dosis 0.3 dan 0.6 memberikan efek penurunan kolesterol yang tidak berbeda. Demikian pula tiap pasang kelompok $\mathrm{MW}$ dengan $\mathrm{MW}+\alpha$-tocopherol pada semua dosis menunjukkan efek penurunan kolesterol yang tidak berbeda.

Tabel 3.Efek kombinasi minyak wijen dengan $\alpha$ tocopherol pada kadar kolesterol serum

\begin{tabular}{ccccc}
\hline $\begin{array}{c}\text { MW } \\
(\mathbf{m l})\end{array}$ & $\begin{array}{c}\boldsymbol{\alpha} \text { - } \\
\text { tocopherol } \\
(\mathbf{m g})\end{array}$ & $\mathbf{n}$ & $\begin{array}{c}\text { Rerata kadar } \\
\text { Kolesterol } \\
\text { serum }\left(\mathbf{m g . d l}^{-\mathbf{1}}\right)\end{array}$ & Analisis \\
\hline 0.3 & - & 4 & $131.025 \pm 8.68$ & \\
0.3 & 20 & 4 & $120.903 \pm 8.52$ & *Manova \\
0.6 & - & 4 & $109.092 \pm 1.97$ & $(\mathrm{p}=0.012)$ \\
0.6 & 20 & 4 & $95.565 \pm 5.21$ & \\
1.2 & - & 4 & $93.845 \pm 4.37$ & \\
1.2 & 20 & 4 & $92.917 \pm 5.80$ & \\
\hline
\end{tabular}

*Uji statistika Manova terhadap rerata kadar kolesterol serum didapatkan perbedaan yang signifikan antara kelompok minyak wijen (MW) dan kelompok kombinasi minyak wijen dengan $\alpha$-tocopherol $(p=0.012)$.

\section{Hasil pengukuran kadar LDL serum}

Data hasil pengukuran kadar LDL serum (Tabel 4) menunjukkan bahwa terjadi penurunan kadar serum LDL, pada semua kelompok minyak wijen, dengan atau tanpa penambahan $\alpha$ tocopherol. Kelompok MW pada semua dosis (0.3, 0.6 dan $1.2 \mathrm{ml})$ menunjukkan efek menurunkan kadar LDL. Demikian pula dengan kelompok $\mathrm{MW}+\alpha$-tocopherol pada semua dosis $(0.3, \quad 0.6$ dan $1.2 \mathrm{ml})$ mempunyai efek menurunkan kadar LDL. Analisa lanjutan dengan Tukey HSD menunjukkan bahwa kadar LDL yang dibandingkan antar pasangan kelompok $\mathrm{MW}$ dengan $\mathrm{MW}+\alpha$-tocopherol pada dosis yang sama, menunjukkan perbedaan yang tidak bermakna. Selanjutnya dilakukan analisa regresi untuk mengetahui efek penambahan $\alpha$ tocopherol pada minyak wijen dibandingkan dengan minyak wijen sendiri. 
Tabel 4. Efek Kombinasi Minyak Wijen dengan $\alpha$ Tocopherol pada Kadar LDL Serum

\begin{tabular}{ccccc}
\hline $\begin{array}{c}\text { MW } \\
\text { (ml) }\end{array}$ & $\begin{array}{c}\boldsymbol{\alpha} \text {-tocopherol } \\
(\mathbf{m g})\end{array}$ & $\mathbf{n}$ & $\begin{array}{c}\text { Rerata kadar } \\
\text { LDL serum } \\
\text { (mg.dl }^{-1} \text { ) }\end{array}$ & Analisis \\
\hline 0.3 & - & 4 & $31.82 \pm 1.03$ & \\
0.3 & 20 & 4 & $19.65 \pm 1.07$ & *Manova \\
0.6 & - & 4 & $18.28 \pm 0.58$ & (p=0.045) \\
0.6 & 20 & 4 & $15.15 \pm 0.76$ & \\
1.2 & - & 4 & $16.50 \pm 1.11$ & \\
1.2 & 20 & 4 & $14.57 \pm 0.54$ & \\
\hline
\end{tabular}

*Uji statistika Manova terhadap rerata kadar LDL serum, didapatkan perbedaan yang bermakna antara kelompok minyak wijen (MW) dan kelompok kombi-nasi minyak wijen dengan $\alpha$-tocopherol $(p=0.045)$

Hasil analisis regresi menunjukkan adanya dua persamaan garis yang berbeda, antara kelompok minyak wijen saja dengan yang ditambah $\alpha$-tocopherol. Kelompok MW menunjukkan adanya hubungan dosis - efek, yang berarti bahwa penambahan dosis minyak wijen berpengaruh terhadap penurunan kadar LDL. Dosis $0.3 \mathrm{ml}$ menunjukkan penurunan kadar LDL yang lebih bermakna daripada dosis 0.6 dan $1.2 \mathrm{ml}$. Pemberian dosis 0.6 dan $1.2 \mathrm{ml}$ akan memberikan efek penurunan kadar LDL yang tidak berbeda. Sedangkan pada perlakuan MW + $\alpha$-tocopherol, menunjukkan tidak adanya garis linear, hal ini menunjukkan terdapat hubungan dosis - efek tetapi efek tiap dosis belum tentu diikuti dengan besarnya penurunan kadar LDL yang sama. Dosis $1.2 \mathrm{ml}$ menurunkan kadar kolesterol lebih bermakna daripada dosis 0.3 dan $0.6 \mathrm{ml}$. Pada dosis 0.3 dan $0.6 \mathrm{ml}$ memberikan efek penurunan yang tidak berbeda. Demikian pula terhadap tiap pasang kelompok MW dengan $\mathrm{MW}+\alpha$-tocopherol pada tiap dosis menunjukkan efek penurunan LDL yang tidak berbeda.

\section{Hasil pengukuran kadar MDA jaringan ginjal}

Data pada Tabel 5 menunjukkan bahwa terjadi penurunan kadar MDA, pada semua kelompok minyak wijen, dengan atau tanpa penambahan $\alpha$-tocopherol. Kelompok MW pada semua dosis (0.3, 0.6 dan $1.2 \mathrm{ml}$ ) menunjukkan efek menu-runkan MDA. Demikian pula dengan kelom-pok $\mathrm{MW}+\alpha$-tocopherol pada semua dosis (0.3, 0.6 dan $1.2 \mathrm{ml})$ mempunyai efek menurunkan kadar MDA. Analisis lanjutan dengan Tukey HSD menunjukkan bahwa kadar MDA yang diban-dingkan antar pasangan kelompok $\mathrm{MW}$ dengan $\mathrm{MW}+\alpha$-tocopherol pada dosis yang sama, menunjukkan perbedaan yang bermakna pada pasangan kelompok $\mathrm{MW}$ dengan $\mathrm{MW}+\alpha-$ tocopherol pada dosis $0.3 \mathrm{ml}(p=0.000)$ dan dosis $0.6 \mathrm{ml}(\mathrm{p}=0.001)$. Selanjutnya dilakukan analisa regresi untuk mengetahui efek penambahan $\alpha$-tocopherol pada minyak wijen dibandingkan dengan minyak wijen sendiri.

Tabel 5. Efek Kombinasi Minyak Wijen dengan $\alpha$ Tocopherol pada Kadar MDA jaringan ginjal

\begin{tabular}{|c|c|c|c|c|}
\hline $\begin{array}{l}\text { MW } \\
\text { (ml) }\end{array}$ & $\begin{array}{c}\alpha- \\
\text { tocopherol } \\
\text { (mg) }\end{array}$ & $\mathbf{n}$ & $\begin{array}{c}\text { Rerata kadar } \\
\text { MDA (nmol.gr } \\
\text { jaringan) }\end{array}$ & Analisis \\
\hline 0.3 & - & 4 & $0.822 \pm 0.506$ & \\
\hline 0.3 & 20 & 4 & $0.558 \pm 0.413$ & *Manova \\
\hline 0.6 & - & 4 & $0.654 \pm 0.162$ & $(p=0.000)$ \\
\hline 0.6 & 20 & 4 & $0.432 \pm 0.209$ & **Tukey \\
\hline 1.2 & - & 4 & $0.506 \pm 0.230$ & HSD \\
\hline 1.2 & 20 & 4 & $0.366 \pm 0.197$ & \\
\hline
\end{tabular}

*Uji statistika Manova terhadap rerata kadar MDA menunjukkan perbedaan bermakna antara kelompok MW dan kelompok kombinasi MW dengan $\alpha$-tocopherol $(\mathrm{p}=$ 0.000)

**Uji statistik lanjutan Tukey HSD menunjukkan terdapat perbedaan bermakna kadar MDA antara pasangan kelompok MW dengan $\mathrm{MW}+\alpha$-tocopherol pada dosis $0.3 \mathrm{ml}(\mathrm{p}=0.000)$ dan dosis $0.6 \mathrm{ml}(\mathrm{p}=0.001)$

Hasil analisis regresi menunjukkan adanya dua persamaan garis yang berbeda, antara kelompok MW dengan $\mathrm{MW}+\alpha$-tocopherol. Kelompok MW tampak menunjukkan adanya hubungan dosis - efek, yang berarti bahwa penambahan dosis minyak wijen berpengaruh terhadap penurunan kadar MDA. Pada masing masing dosis $(0.3,0.6$ dan $1.2 \mathrm{ml})$ kelompok $\mathrm{MW}$ menunjukkan penurunan kadar MDA yang berbeda. Sedangkan dari garis $\mathrm{MW}+\alpha$-tocopherol, juga menunjukkan terdapat hubungan dosis - efek. Seperti halnya pada kelompok MW, kelompok $\mathrm{MW}+\alpha$-tocopherol menunjukkan bahwa pada masing - masing dosis terjadi penurunan kadar MDA yang berbeda. Bila dibandingkan penurunan kadar MDA antara pasangan kelompok $\mathrm{MW}$ dan $\mathrm{MW}+\alpha$-tocopherol menunjukkan perbedaan bermakna pada dosis 0.3 dan $0.6 \mathrm{ml}$.

\section{Hasil pengukuran kadar SOD jaringan ginjal}

Data pengukuran kadar SOD jaringan ginjal menunjukkan bahwa terjadi peningkatan kadar SOD, pada semua kelompok minyak wijen, dengan atau tanpa penambahan $\alpha$-tocopherol (Tabel 6). Kelompok MW pada semua dosis (0.3, 0.6 dan $1.2 \mathrm{ml}$ ) menunjukkan efek meningkatkan SOD. Demikian pula dengan kelompok $\mathrm{MW}+\alpha-$ tocopherol pada semua dosis (0.3, 0.6 dan 1.2 $\mathrm{ml}$ ) mempunyai efek meningkatkan kadar SOD. 
Analisa lanjutan dengan Tukey HSD menunjukkan bahwa kadar SOD yang dibandingkan antar pasangan kelompok MW dengan $\mathrm{MW}+\alpha$-tocopherol pada dosis yang sama, menunjukkan perbedaan yang tidak bermakna. Selanjutnya dilakukan analisa regresi untuk mengetahui efek penambahan $\alpha$ tocopherol pada minyak wijen dibandingkan dengan minyak wijen sendiri.

Tabel 6. Efek Kombinasi Minyak Wijen dengan $\alpha$ Tocopherol pada Kadar SOD

\begin{tabular}{|c|c|c|c|c|}
\hline $\begin{array}{l}\text { MW } \\
\text { (ml) }\end{array}$ & $\begin{array}{c}\alpha- \\
\text { tocopherol } \\
\text { (mg) }\end{array}$ & n & $\begin{array}{l}\text { Rerata kadar } \\
\text { SOD serum } \\
\text { (U.gr }{ }^{-1} \text { jaringan) }\end{array}$ & Analisis \\
\hline 0.3 & - & 4 & $209.46 \pm 15.20$ & \multirow{6}{*}{$\begin{array}{c}{ }^{*} \text { Manova } \\
(p=0.000)\end{array}$} \\
\hline 0.3 & 20 & 4 & $229.08 \pm 11.84$ & \\
\hline 0.6 & - & 4 & $241.77 \pm 16.07$ & \\
\hline 0.6 & 20 & 4 & $267.82 \pm 17.82$ & \\
\hline 1.2 & - & 4 & $284.45 \pm 16.32$ & \\
\hline 1.2 & 20 & 4 & $340.52 \pm 17.38$ & \\
\hline
\end{tabular}

*Uji statistika Manova terhadap rerata kadar SOD, menunjukkan perbedaan bermakna antara kelompok minyak wijen dan kelompok kombinasi minyak wijen dengan $\alpha$-tocopherol $(p=0.000)$.

Hasil analisis regresi menunjukkan adanya dua persamaan garis yang berbeda, antara kelompok minyak wijen saja dengan yang ditambah $\alpha$-tocopherol. Kelompok MW tampak berbentuk linear dan menunjukkan adanya hubungan dosis - efek, yang berarti bahwa penambahan dosis minyak wijen berpengaruh terhadap peningkatan kadar SOD. Berdasarkan data tersebut, kelompok MW menunjukkan bahwa dosis $0.3 \mathrm{ml}$ dan $0.6 \mathrm{ml}$ memberikan efek peningkatan kadar SOD yang tidak berbeda, demikian pula dengan dosis 0.6 dan $1.2 \mathrm{ml}$; hal ini berarti bahwa pada dosis 0.6 memberikan efek peningkatan kadar SOD yang paling nyata. Sedangkan kelompok $\mathrm{MW}+\alpha$-tocopherol, menunjukkan bentuk linear dan juga terdapat hubungan dosis - efek. Pada kelompok ini juga menunjukkan bahwa pada dosis 0.3 dan 0.6 memberikan efek peningkatan SOD yang tidak berbeda, sedangkan pada dosis 1.2 efek peningkatan kadar SOD nya paling bermakna. Analisa Tukey HSD terhadap tiap pasang dosis $\mathrm{MW}$ dengan $\mathrm{MW}+\alpha$-tocopherol menunjukkan perbedaan yang tidak bermakna.

\section{Hasil pengamatan histologis glomerulus}

Data pengamatan luas matriks mesangial (Tabel 7) menunjukkan terjadi penurunan \% matriks baik pada minyak wijen sendiri maupun dengan penambahan $\alpha$-tocopherol. Dari analisa statistik didapatkan perbedaan tidak bermakna pada \% luas matriks mesangial antara kelompok $\mathrm{MW}$ dengan kelompok $\mathrm{MW}+\alpha$-tocopherol $(\mathrm{p}=$ 0.614 ). Hasil penghitungan $\%$ matriks selanjutnya dilakukan grading terhadap glomerular injury berdasarkan \% luasnya matriks. Terdapat penurunan grading glomerular injury, dimana grade yang lebih rendah didapatkan pada kelompok kombinasi MW dan $\alpha$-tocopherol pada dosis 0,6 $\mathrm{ml}$ dan $1,2 \mathrm{ml}$.

Hasil penghitungan terhadap rerata jumlah sel mesangial menunjukkan adanya penurunan jumlah sel mesangial pada semua kelompok perlakuan (Tabel 8). Kelompok MW pada semua dosis menunjukkan efek menurunkan jumlah sel mesangial. Demikian pula pada kelompok MW + $\alpha$-tocopherol. Analisa lanjutan dengan Tukey HSD menunjukkan bahwa jumlah sel mesangial yang dibandingkan antar pasangan kelompok MW dengan $\mathrm{MW}+\alpha$-tocopherol pada dosis yang sama, menunjukkan perbedaan yang tidak bermakna.

Hasil analisis regresi menunjukkan adanya dua persamaan garis linear yang berbeda, antara kelompok MW saja dengan yang ditambah $\alpha$ tocopherol. Garis kelompok MW tampak berbentuk linear dan menunjukkan adanya hubungan dosis-efek. Hal ini berarti bahwa penambahan dosis minyak wijen berpengaruh terhadap penurunan jumlah sel mesangial.

Tabel 7. Efek Kombinasi Minyak Wijen (MW) dengan $\alpha$-Tocopherol terhadap Presentase Luas Matriks Mesangial

\begin{tabular}{cccccc}
\hline MW (ml) & $\boldsymbol{\alpha}$-tocopherol $(\mathbf{m g})$ & $\mathbf{n}$ & Rerata Persentase Luas Matriks (\%) & Grading & Analisis \\
\hline Hiperkolesterol & & 4 & $53.95 \pm 2.09$ & 3 & \\
0.3 & - & 4 & $52.91 \pm 2.09$ & 3 & \\
0.3 & 20 & 4 & $50.38 \pm 3.48$ & 3 & $*$ Manova \\
0.6 & - & 4 & $50.98 \pm 3.21$ & 3 & $(\mathrm{p}=$ \\
0.6 & 20 & 4 & $49.15 \pm 2.10$ & 3 & $.614)$ \\
1.2 & - & 4 & $49.90 \pm 2.97$ & 3 & \\
1.2 & 20 & 4 & $46.16 \pm 1.19$ & 3 & \\
\hline
\end{tabular}

*Uji statistika manova terhadap rerata persentase luas matriks mesangial menunjukkan tidak terdapat perbedaan bermakna pada antara kelompok minyak wijen (MW) dan kelompok kombinasi minyak wijen dengan $\alpha$-tocopherol pada berbagai dosis ( $p$ $=0.614)$. 
(Sukmawati)

Tabel 8. Efek Kombinasi Minyak Wijen dengan $\alpha$ Tocopherol terhadap Jumlah Sel Mesangial

\begin{tabular}{ccccc}
\hline $\begin{array}{c}\text { MW } \\
(\mathbf{m l})\end{array}$ & $\begin{array}{c}\boldsymbol{\alpha} \text { - } \\
\text { tocopherol } \\
(\mathbf{m g})\end{array}$ & $\mathbf{n}$ & $\begin{array}{c}\text { Rerata } \\
\text { Jumlah Sel } \\
\text { Mesangial }\end{array}$ & Analisis \\
\hline Hiperkolesterol & & 4 & $27.75 \pm 1.2$ & \\
0.3 & - & 4 & $22.12 \pm 0.85$ & \\
0.3 & 20 & 4 & $20.31 \pm 0.47$ & $*$ Manova \\
0.6 & - & 4 & $20.94 \pm 0.33$ & $(p=0.000)$ \\
0.6 & 20 & 4 & $18.88 \pm 0.66$ & \\
1.2 & - & 4 & $17.62 \pm 0.46$ & \\
1.2 & 20 & 4 & $16.31 \pm 0.40$ & \\
\hline
\end{tabular}

*Uji statistika manova terhadap rerata jumlah sel mesangial, menunjukkan terdapat perbedaan yang bermakna antara kelompok MW dan kelompok kombinasi MW dengan $\alpha$-tocopherol $(\mathrm{p}<0.05)$.

Hal ini berarti bahwa penambahan dosis minyak wijen berpengaruh terhadap penurunan jumlah sel mesangial. Pada kelompok $\mathrm{MW}$ menunjukkan bahwa pada dosis 0.3 dan $0.6 \mathrm{ml}$ menunjukkan efek penurunan jumlah sel mesangial yang tidak berbeda. Pada dosis $1.2 \mathrm{ml}$ memberikan efek penurunan jumlah sel yang bermakna. Sedangkan dari garis $\mathrm{MW}+\alpha-$ tocopherol menunjukkan bentuk linear dan juga terdapat hubungan dosis - efek. Seperti halnya kelompok MW, pada kelompok $\mathrm{MW}+\alpha$ tocopherol, pada dosis 0.3 dan $0.6 \mathrm{ml}$ menunjukkan efek penurunan jumlah sel mesangial yang tidak berbeda. Sedangkan pada dosis $1.2 \mathrm{ml}$ menunjukkan efek penurunan yang bermakna. Analisa terhadap pasangan kelompok $\mathrm{MW}$ dengan $\mathrm{MW}+\alpha$-tocopherol pada dosis yang sama menunjukkan perbedaan tidak bermakna.

Hasil pengamatan dan analisis sediaan histologis glomerulus menunjukkan bahwa jumlah sel mesangial dan luas matriks adalah lebih banyak didapatkan pada kelompok hiperkolesterol daripada kelompok minyak wijen. Pada kelompok hiperkolesterol (Gambar 2) tampak adanya peningkatan densitas dalam glomerulus (adanya penebalan pada lapisan luar kapsul pembungkus glomerulus (parietal layer of Bowman's capsule), meningkatnya jumlah sel intraglomerulus disertai peningkatan matriks ekstraseluler. Juga didapatkan kapiler dalam glomerulus tidak tampak terbuka.

Sedangkan pada kelompok perlakuan minyak wijen baik sendiri menunjukkan adanya perbaikan struktur glomerulus dibanding kelompok hiperkolesterol, ditandai kapsula Bowman yang lebih tipis, berkurangnya jumlah sel intraglomerulus dan matriks ekstraseluler, serta tampak adanya kapiler yang terbuka.

Demikian pula pada kelompok kombinasi dengan $\alpha$-tocopherol (Gambar 2) tampak lebih

baik lagi, ditandai dengan lapisan kapsul luar yang tidak menebal, jumlah sel intraglomerular dan matriks ekstraseluler sedikit, sehingga tampak kapiler yang terbuka dan terisi sel - sel darah. Penambahan $\alpha$-tocopherol menunjukkan gambaran histologis glomerulus yang lebih baik dibanding kelompok hiperkolesterol dan minyak wijen sendiri.

HK
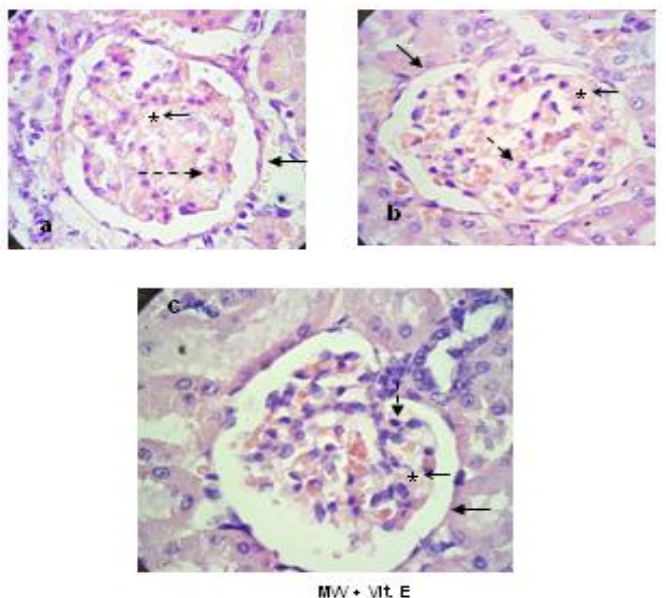

Gambar 2. Perubahan histopatologi pada glomerulus ginjal dengan pengecatan Periodic Acids Schiff pembesaran $1000 x$

- * : matriks mesangial

$\longrightarrow$ : penebalan membran luar glomerulus (kapsula Bowman)

$\longrightarrow \quad$ : sel mesangial

\section{Hasil pengukuran kadar ureum dan kretinin}

Tabel 9 dan 10 menunjukkan bahwa kadar ureum dan kreatinin tidak banyak berubah dengan pemberian minyak wijen saja maupun dengan penambahan $\alpha$-tocopherol pada keadaan hiperkolesterol. Hal ini ditunjukkan dengan hasil analisa manova yang tidak signifikan.

Tabel 9. Efek Kombinasi Minyak Wijen dengan $\alpha$ Tocopherol pada Kadar Ureum

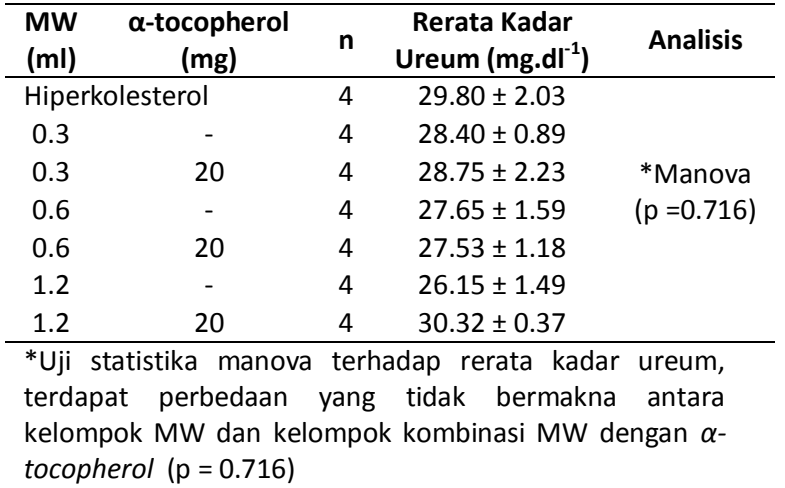


Tabel 10. Efek Kombinasi Minyak Wijen dengan $\alpha$ Tocopherol pada Kadar Kreatinin

\begin{tabular}{|c|c|c|c|c|}
\hline $\begin{array}{l}\text { MW } \\
\text { (ml) }\end{array}$ & $\begin{array}{l}\alpha \text {-tocopherol } \\
\text { (mg) }\end{array}$ & $\mathrm{n}$ & $\begin{array}{c}\text { Rerata Kadar } \\
\text { Kreatinin } \\
\left(\mathrm{mg} . \mathrm{dl}^{-1}\right)\end{array}$ & Analisis \\
\hline 0.3 & - & 4 & $0.698 \pm 2.03$ & \multirow{7}{*}{$\begin{array}{l}\text { *Manova } \\
(p=0.711)\end{array}$} \\
\hline 0.3 & 20 & 4 & $0.692 \pm 0.005$ & \\
\hline 0.6 & - & 4 & $0.657 \pm 0.049$ & \\
\hline 0.6 & 20 & 4 & $0.657 \pm 0.053$ & \\
\hline 1.2 & - & 4 & $0.622 \pm 0.060$ & \\
\hline 1.2 & 20 & 4 & $0.607 \pm 0.070$ & \\
\hline \multicolumn{2}{|c|}{ Hiperkolesterol } & 4 & $0.788 \pm 00.40$ & \\
\hline
\end{tabular}

Keterkaitan stres oksidatif dan glomerular injury

Dari hasil analisa korelasi antara parameter stres oksidatif dengan parameter glomerular injury pada kelompok MW dan kelompok MW + $\alpha$-tocopherol menunjukkan bahwa pada kelompok MW terdapat korelasi bermakna antara MDA dengan SOD ( $p=0.021)$; MDA dengan jumlah sel $(p=0.002)$ dan SOD dengan jumlah sel ( $p=$ 0.031). Sedangkan pada kelompok $\mathrm{MW}+\alpha$ tocopherol terdapat korelasi bermakna antara kadar MDA dengan SOD $(p=0.040)$ dan kadar MDA dengan jumlah sel mesangial $(p=0.015)$.

\section{PEMBAHASAN}

Berdasarkan penelitian ini diperoleh hasil bahwa minyak wijen dapat menurunkan kadar kolesterol total dan LDL serum pada pada semua kelompok. Mekanisme yang mendasari efek hipolipidemi minyak wijen diduga adalah karena kandungan PUFA nya yang tinggi, yaitu $85 \%$ dari asam lemaknya [8]. Hipothesis terbaru menyatakan bahwa PUFA mampu mengendalikan ekspresi gen oksidatif melalui aktivasi faktor transkripsi peroxisome prolife rator-activated receptor- $\alpha$ (PPAR- $\alpha$ ), yang merupakan suatu lipid-activated transcription factor, berperan sebagai ligan dan meningkatkan interaksi PPAR- $\alpha$ dengan DNA (deoxyribo nukleat acid). PUFA juga menurunkan produksi enzim malonyl-CoA di hepar yang berperan dalam menghambat enzim carnitine palmitoyl-transfe rase yang berfungsi memperantarai masuknya asam lemak ke dalam mitokondria dan peroksisom, untuk mengalami proses oksidasi.

Minyak wijen juga mengandung lignan sesamin. Sejumlah penelitian menunjukkan bahwa sesamin mempunyai efek hipolipidemik. Sesamin merupakan suatu ligan PPAR aktif dan merupakan induser kuat terhadap oksidasi asam lemak. Sesamin juga menurunkan ekspresi gen enzim-enzim lipogenik hepar dengan menurunkan SREBP-1. Perubahan kecepatan sintesis dan oksidasi asam lemak dalam hepar dapat mempengaruhi konsentrasi lipid serum. Hal ini selanjutnya berpengaruh terhadap avaibilitas asam lemak untuk sintesis triasilgliserol, yang pada akhirnya akan mempengaruhi produksi VLDL oleh hepar. Berkurangnya produksi lipoprotein oleh hepar mendasari efek hipolipidemik dari sesamin [20].

Hasil penelitian ini menunjukkan penurunan kadar serum kolesterol total dan LDL yang paling baik adalah pada dosis minyak wijen $1.2 \mathrm{ml}$ (24\% kalori) baik dengan tambahan $\alpha$-tocopherol maupun tidak. Sehingga dapat diasumsikan bahwa ini merupakan dosis minyak wijen yang paling baik dalam menurunkan kadar kolesterol dan LDL. Pada tikus dengan diet kolesterol dan asam kolat yang diberi minyak wijen $24 \%$ juga menunjukkan penurunan signifikan kadar serum kolesterol total dan LDL [21].

Dari analisis data didapatkan hasil bahwa pada semua kelompok dapat menurunkan kadar kolesterol total dan LDL, baik yang diberi tambahan $\alpha$-tocopherol maupun tidak. Hal ini menunjukkan bahwa minyak wijen mempunyai efek hipolipidemik, penambahan $\alpha$-tocopherol menunjukkan kemampuan lebih menurunkan kadar kolesterol dan LDL, meskipun tidak bermakna. Namun diduga terdapat kecenderungan adanya interaksi antara $\alpha$-tocopherol dengan minyak wijen secara potensiasi. Yaitu bahwa efek penurunan kadar kolesterol dan LDL cenderung meningkat dengan penambahan $\alpha$ tocopherol (yang tidak mempu-nyai efek hipolipidemik) pada minyak wijen yang diketahui mempunyai efek hipolipidemik. Hal ini berdasarkan pada analisis regresi yang menunjukkan 2 garis dengan persamaan yang berbeda dari hasil regresi, yang menggambarkan hubungan dosisefek. Selain itu antar pasangan kelompok MW dengan $\mathrm{MW}+\alpha$-tocopherol pada dosis yang sama menunjukkan bahwa penam-bahan $\alpha$ tocopherol tampak lebih mampu menurunkan kadar kolesterol, meskipun secara statistik efek masing-masing pasangan dosis tersebut tidak bermakna. Hal ini kemungkinan berhubungan dengan jumlah sampel yang sedikit serta perlunya penambahan dosis $\alpha$-tocopherol secara serial untuk mengetahui dosis efektifnya.

Pemberian minyak wijen mampu menurunkan kadar malondialdehyde (MDA) jaringan ginjal pada semua kelompok. Penambahan $\alpha$ tocopherol pada dosis minyak wijen 0.3 dan 0.6 
menunjukkan perbedaan yang bermakna bila dibandingkan dengan minyak wijen saja pada dosis yang sama. MDA merupakan salah satu indikator terjadinya peroksidasi lipid, akibat adanya stres oksidatif. Kemampuan minyak wijen untuk menurunkan kadar MDA adalah karena kandungan antioksidan alaminya yang berupa lignan, yaitu sesamolin [8]. Sesamolin merupakan antioksidan yang bekerja sebagai scavenger terhadap radikal peroksil yang terbentuk. Pemberian sesamolin 1\% pada tikus SpragueDawley terbukti menurunkan kadar MDA pada jaringan ginjal dan hepar secara bermakna [11].

Alpha-tocopherol diketahui sebagai antioksidan yang bekerja dengan memutus reaksi berantai dengan melakukan scavenger terhadap radikal peroksil. Dalam hal ini penambahan $\alpha$ tocopherol pada minyak wijen menunjukkan efek yang sinergistik. Artinya efek minyak wijen dalam menurunkan kadar MDA diperkuat dengan penambahan $\alpha$-tocopherol. Kadar TBARS hepar lebih rendah pada kelompok dengan penambahan vitamin $\mathrm{E}$ dalam minyak ikan dibanding yang tanpa suplemen $\alpha$-tocopherol [22].

SOD merupakan antioksidan enzimatik yang pertama kali bekerja ketika ROS dihasilkan. Minyak wijen terbukti dapat meningkatkan kada SOD pada semua kelompok. Penambahan $\alpha$ tocopherol pada minyak wijen menunjukkan kecenderungan untuk lebih meningkatkan kadar SOD dibanding kelompok MW saja pada ketiga dosis. Hal ini kemungkinan karena dengan adanya $\alpha$-tocopherol maka kerja dari SOD menjadi lebih berkurang karena stres oksidatif yang terjadi sudah diatasi oleh minyak wijen dan $\alpha$-tocopherol yang diduga saling berinteraksi secara sinergis. Dugaan sinergistik antara $\alpha$ tocopherol dengan minyak wijen terhadap kadar SOD adalah berdasarkan analisis regresi yang menunjukkan bahwa terdapat dua garis linier dengan persamaan yang berbeda dan menunjukkan adanya hubungan dosis-efek. Masingmasing garis/ kelompok juga menunjuk-kan efek yang berbeda dalam meningkatkan kadar SOD.

Gambaran histologis menunjukkan adanya perubahan glomerulus pada kelompok hiperkolesterol. Perubahan ini ditandai dengan adanya penebalan pada membran luar (kapsula Bow man), akumulasi matriks mesangial serta adanya proliferasi sel mesangial. Perubahan ini mengarah pada terjadinya sklerosis glomerular. Hal ini dapat dijelaskan bahwa hiperkolesterolemia meningkatkan pembentukan ROS. Selanjutnya ROS dapat menyebabkan oksidasi dan modifikasi LDL. Sel mesangial mengekspresikan reseptor scavenger yang terlibat dalam kecenderungan untuk melakukan ambilan (uptake) LDL teroksidasi dan termodifikasi. Paparan terhadap LDL teroksidasi ini selanjutnya akan menstimulasi sel mesangial untuk mensekresi sejumlah faktor kemotaktik dan molekul adhesi (M-CSF, ICAM-1, VCAM-1) yang akan meningkatkan pengerahan makrofag intramesangial.

Makrofag teraktivasi ini selanjutnya menstimulasi pelepasan ROS dan ekspresi sitokin prosklerotik dan proliferatif seperti transforming growth factor - $\beta$ (TGF- $\beta$ ) dan platelet-derived growth factor- $A B$ (PDGF-AB). Sitokin ini akan menstimulasi produksi protein matriks ekstraseluler dan proliferasi sel mesangial. Studi in vitro menunjukkan bahwa LDL dan LDL teroksidasi juga dapat menstimulasi ekspresi gen TGF- $\beta$ pada sel mesangial dan epithelial glomerular [23].

Hasil pengamatan sediaan histologis menunjukkan bahwa dengan pemberian minyak wijen pada semua kelompok terdapat gambaran efek perbaikan terhadap glomerular injury. Hal ini ditandai dengan berkurangnya penebalan pada membran luar glomerulus, akumulasi matriks mesangial (dinyatakan dalam \% luas matriks mesangial) juga berkurang, serta menurunnya jumlah sel mesangial. Luas matriks mesangial ditunjukkan dalam \% luas matriks menunjukkan penurunan dengan pemberian kombinasi minyak wijen dengan $\alpha$-tocopherol, namun tidak bermakna $(p=0.614)$. Hal ini menunjukkan bahwa ada faktor lain yang lebih berpengaruh terhadap akumulasi matriks mesangial, dan tidak hanya melalui aktivitas stres oksidatif. Kemungkinan adanya interaksi sejumlah growth faktor yang berperan secara autokrin dan parakrin dalam mempengaruhi sintesis matriks mesangial, sehingga penambahan $\alpha$ tocopherol untuk meningkatkan efek penghambatan trehadap stres oksidatif tidak banyak berpengaruh.

Hasil penurunan \% luas matriks mesangial yang tidak bermakna juga dapat disebabkan oleh faktor keterbatasan cara pengukuran luas matriks. Pada penelitian ini \% luas matriks dihitung dengan membagi luas matriks dengan luas total glomerulus yang mengisi kotak mikrometer square. Sehingga kemungkinan kurang menggambarkan luas matriks yang sesungguhnya, karena didalam matriks tersebut juga terdapat sel-sel intraglomerular yang dapat ikut terhitung/mempengaruhi penghitungan luas 
matriks mesangial. Disamping itu, teknik pengecatan yang digunakan adalah metode PAS yang bertujuan mewarnai gugus polisakarida dari glikosaminoglikan yang merupakan komponen penting dari matriks jaringan ikat. Sehingga tidak spesifik mewarnai komponen matriks yang meningkat, yang dapat lebih memudahkan kuantifikasi terhadap luas matriks mesangial.

Gambaran histologis pada semua kelompok juga menunjukkan penurunan jumlah sel mesangial. Hasil pengamatan terhadap kepadatan sel intraglomerulus menunjukkan berkurangnya jumlah sel mesangial pada semua kelompok dengan pemberian minyak wijen, dibanding kelompok hiperkolesterol. Kepadatan sel ini tampak semakin berkurang dengan meningkatnya dosis minyak wijen, dan tampak lebih baik dengan penambahan $\alpha$-tocopherol. Hal ini menunjukkan bahwa minyak wijen diduga mempunyai kemampuan menghambat proliferasi sel mesangial. Penambahan $\alpha$-tocopherol pada minyak wijen tampak lebih menurunkan jumlah sel mesangial, dibanding minyak wijen sendiri meskipun secara statistik tidak bermakna. Namun terdapat dugaan adanya interaksi potensiasi antara $\alpha$-tocopherol dengan minyak wijen terhadap penurunan jumlah sel mesangial.

Alpha - tocopherol diketahui mempunyai efek antiproliferasi pada sel otot polos pembuluh darah melalui hambatan terhadap Protein Kinase-C (PKC). Sejumlah penelitian lain juga menunjukkan adanya efek penghambatan PKC pada sel makrofag, neutrophil, fibroblas dan sel mesangial oleh $\alpha$-tocopherol [24]. Sedangkan minyak wijen tidak mempunyai efek antiproliferasi. Dari hasil regresi, menun-jukkan dugaan adanya interaksi potensiasi antara $\alpha$-tocopherol dengan minyak wijen.

Hasil penghitungan terhadap jumlah sel mesangial yang menurun namun tidak bermakna secara statistik ini kemungkinan juga dapat disebabkan faktor keterbatasan identifikasi sel mesangial saat menghitung sel. Meskipun disebutkan bahwa sel mesangial dapat diidentifikasi dengan keakuratan yang beralasan berdasarkan lokasinya yang terletak di antara kapiler, mempunyai multiple prosesus ekstraseluler, inti reguler dengan sitoplasma kurang padat dan kadang terdapat granul sitoplasmik, namun juga diketahui bahwa normal jumlah sel mesangial hanya sekitar sepertiga dari total jumlah sel dalam glomerulus tikus Wistar [25] sehingga lebih didominasi sel yang lain. Selain itu juga disebutkan bahwa hampir semua glomeruli pada tikus dapat terkontaminasi/mengandung subpopulasi sel yang mengekspresikan reseptor la antigen dan reseptor $\mathrm{Fc}$ dengan kemampuan fagositosis, yang diduga adalah infiltrasi sel makrofag, terutama pada glomeruli yang mengalami inflamasi dan terletak pada area mesangium. Sel ini tidak dengan mudah dapat dibedakan dari sel mesangial intrinsik, kecuali dengan pewarnaan khusus terhadap reseptor tersebut atau pengamatan dengan mikroskop elektron [25]. Hal - hal ini dapat mempengaruhi penghitungan jumlah sel mesangial.

Secara umum, pemberian minyak wijen sendiri maupun kombinasi dengan $\alpha$-tocopherol terhadap parameter glomerular injury, yaitu jumlah sel mesangial dan \% luas matriks mesangial menunjukkan efek perbaikan/protektif dengan menurunkan jumlahnya, meskipun secara statistik tidak bermakna. Hal ini kemungkinan juga dipengaruhi adanya sel lain yang tidak ikut dihitung, namun dapat berpengaruh terhadap proses terjadinya glomerular injury; yaitu sel makrofag.

Meningkatnya sintesis matriks ekstraseluler terutama tergantung pada aktivasi sel mesangial (proliferasi, produksi matriks dan cytokinegrowth factor). Sel mesangial dapat teraktivasi secara langsung oleh LDL atau LDL teroksidasi, yang akan menstimulasi sintesis matriks, protein kinase $C$ (PKC) serta sintesis TGF- $\beta$ dan PDGF dengan efek autokrin. Sementara, secara in vivo sel mesangial dapat distimulasi secara tidak langsung oleh suatu tipe sel yang terdapat dalam glomerulus, diduga sel ini adalah makrofag. Karena kemampuannya untuk menginfiltrasi jaringan dari aliran darah dan untuk menghasilkan paracrine growth factor. Makrofag ini diketahui ikut terlibat pada berbagai kondisi patologis injury pada ginjal.

Pengerahan makrofag dalam glomerulus tikus yang diinduksi hiperglikemia dengan model Streptozotocin, adalah berkaitan dengan meningkatnya sintesis mRNA rantai $\alpha_{1}$ kolagen tipe IV dalam glomeruli dan juga berkaitan dengan perubahan struktur glomerulus. Infiltrasi makrofag ini diperantarai oleh ekspresi molekul adhesi dan faktor kemotaktik. Selain itu juga melibatkan IL-1 $\beta$, yang ikut berperan dalam sintesis kolagen tipe IV dan molekul adhesi [26].

Hasil analisis korelasi menunjukkan bahwa penambahan $\alpha$-tocopherol pada minyak wijen meningkatkan efek protektif dalam menghambat glomerular injury melalui penghambatan stres 
oksidatif, dibanding minyak wijen sendiri. Sedangkan pada analisis kadar SOD dengan jumlah sel mesangial menunjukkan korelasi yang tidak bermakna ( $p=0.60)$, hal ini menunjukkan bahwa kerja dari SOD sebagai antioksidan menjadi berkurang dengan penambahan $\alpha$ tocopherol pada minyak wijen, karena sudah dibantu oleh $\alpha$-tocopherol, sehingga efeknya terhadap jumlah sel mesangial menjadi berkurang/tidak nyata.

Hasil analisis pengaruh diet hiperkolestrol terhadap fungsi ginjal mneunjukkan tidak terdapat pengaruh signifikan antara diet hiperkolesterol terhadap gangguan fungsi ginjal. Seiring dengan hal tersebut, pemberian minyak wijen, baik sendiri maupun kombinasi dengan vitamin $E$ tidak memberikan pengaruh yang bermakna. Hal ini dapat dimengerti karena perubahan konsentrasi kreatinin serum baru terlihat bila didahului gangguan fungsi ginjal yang signifikan, seringkali $>50 \%$ penurunan kecepatan filtrasi glomerular (GFR). Demikian pula dengan kadar ureum, peningkatan kadar ureum plasma harus didahului dengan kerusakan glomerular sebesar $70-80 \%$ [27].

Selain itu, hal ini kemungkinan juga berarti bahwa kerusakan jaringan/glomerular injury yang terjadi memang belum cukup parah. Induksi dengan hiperkolesterol saja selama 10 minggu pada penelitian ini ternyata belum menimbulkan kerusakan yang parah pada glomerulus. Hal ini sesuai dengan keadaan pada sejumlah pasien dengan hiperkolesterol primer, yang tidak selalu disertai dengan penyakit renal. Kadar kolesterol plasma yang tinggi saja tidak selalu berkorelasi dengan glomerulosklerosis (yang ditandai dengan meningkatnya jumlah sel intraglomerulus dan ekspansi matriks ekstra-sluler), namun perlu disertai keterlibatan faktor lain yang dapat mempercepat dan mempengaruhi perkembangan disfungsi renal yang diinduksi oleh lipid. Faktor ini antara lain adalah terdapatnya hipertensi intra-renal dan proses inflamasi dalam glomerulus [28].

\section{KESIMPULAN}

Penambahan $\alpha$-tocopherol pada minyak wijen cenderung lebih menurunkan kadar kolesterol total dan LDL dibanding minyak wijen saja, dan diduga terdapat interaksi secara potensiasi. Penambahan $\alpha$-tocopherol pada minyak wijen lebih menurunkan kadar MDA jaringan ginjal dibanding minyak wijjen saja, dan terdapat interaksi secara sinergistik, sedangkan terhadap kadar SOD penambahan $\alpha$-tocopherol pada minyak wijen cenderung lebih meningkatkan kadar SOD dibanding minyak wijen saja, dan diduga bahwa keduanya berinteraksi secara sinergis. Penambahan $\alpha$-tocopherol pada minyak wijen cenderung lebih menurunkan \% luas matriks mesangial dan jumlah sel mesangial dibanding minyak wijen saja, dan diduga terdapat interaksi potensiasi penambahan $\alpha$-tocopherol pada minyak wijen terhadap penurunan jumlah sel mesangial. Penambahan $\alpha$-tocopherol pada minyak wijen menunjukkan efek penghambatan aktifitas stress oksidatif yang lebih baik dibanding minyak wijen sendiri dan hal ini dapat menghambat glomerular injury.

\section{Saran}

Perlu dilakukan penelitian lebih lanjut mengenai: efek potensiasi minyak wijen dengan $\alpha$ tocopherol terhadap kadar kolesterol dengan dosis $\alpha$-tocopherol serial dan jumlah sampel yang lebih banyak; peningkatan matriks ekstraseluler dengan lebih tepat, misalnya dengan pewarnaan khusus (imunohistokimia) terhadap komponen matriks yang meningkat, terutama terhadap kolagen tipe IV; pengaruh kombinasi minyak wijen dengan $\alpha$-tocopherol in vitro terhadap proliferasi sel; serta menghitung jumlah makrofag glomerulus dan kaitannya dengan jumlah sel mesangial dan matriks mesangial.

\section{DAFTAR PUSTAKA}

[1] Scaeffner, S. E., T. Kurth, G. C. Curhan, R. J. Glynn, K. M. Rexrode, C. Baigent, J. E. Buring, J. M. Gaziano. 2003. Cholesterol and the risk of renal dysfunction in apparently healthy men. J. Am. Soc. Nephrol. 14. 20842091.

[2] Mauro, V. 2004. Chronic renal failure. www.emedicine.com.htm.

[3] Cheng, G., P. Latha, K. Yuko, S. I. Pravin, D. Wenlan, P. Sivaram. 2001. A protective role for kidney Apolipoprotein E: regulation of Mesangial cell proliferation and matrix expansion. J. Biol. Chem. 52 (276). 4914249147.

[4] Bonnet, F., M. E. Cooper. 2000. Potential influence of lipids in Diabetic Nephropathy: insight from experimental data and clinical studies. Diabetes Metab. 26. 254-264.

[5] Annuk, M., Z. Mihkel, L. Lars, L. Torbjorn, F. Bengt. 2001. Oxidative stress and endothelial function in chronic renal failure. J. Am. Soc. Nephrol. 12. 2747-2752. 
[6] Sharma, M., N. Nitya, H. K. Aggarwal, N. Daya. 2004. Evaluation of effects of Lovastatin on Hypercholesterolaemia and renal functions in Nephrotic Syndrome. JIACM. 5(2). 143-146.

[7] Safeer, R. S., P. S. Ugalat. 2002. Cholesterol treatment guidelines update. Am. Fam. Physician. 65(5). 871-880.

[8] Winarno, F. G. 1990. Tempe, misteri gizi dari Jawa, info pangan. Teknologi Pangan dan Gizi, Institut Pertanian Bogor. Bogor.

[9] Handayani, S., A. Isti, Kusnandar, N. C. Ahmad. 2003. The potential of products based on sesame on agriculture sustainability system in Sukoharjo district, Central Java Province, Sebelas Maret University. International Conference of Food and Agricultura System for Developing Countries. Yogyakarta.

[10] Hirose, N., I. Tsotumo, N. Kazuyoshi, S. Michihiro, A. Kengo, S. Sakayu, Y. Hideaki. 1991. Inhibition of cholesterol absorption and synthesis in rats by sesamin. J. Lipid Res. 32. 629-638.

[11] Kang, M., N. Michitaka, T. Nobuko, O. Toshihiko. 1998. Sesamolin inhibits lipid peroxidation in rat liver and kidney. J. Nutr. 128. 1018-1022.

[12] Gutteridge, J. M. C., H. Barry. 1996. Antioxidants in nutrition, health and disease. Oxford University Press. Oxford. New York. 63- 81.

[13] Kedziora-Kornatowska, K., S. Szram, T. Kornatowski, I. Szadujkis-Szadurski, G. Bartosz. 2003. Effects of vitamin $E$ and vitamin C supplementation on antio and renal glomerular basement membrane thickness in diabetic kidney. Nephrol. 95. 134-143.

[14] Boaz, M. S. Smetana, T. Weinstein, Z. Matas, U. Gafter, A. laina, A. Knecht, Y. Weissgarten, D. Brunner, M. Fainaru, M. S. Green. 2000. Secondary prevention with antioxidants of cardiovascular disease in endstage renal disease (SPACE): randomised placebo-controlled trial. Lancet. 356(9237). 1213-1218.

[15] Brigelius-F, R., J.K. Frank, T.S. Jukka, N. Jiri, Z. Jean-Marc, A. Angelo. 2002. The European perspective on vitamin E: current knowledge and future research. Am J Clin Nutr. 76. 703-16.

[16] Ali, M., I. K., Muliartha. 2002. Model binatang coba tikus Atherosklerosis. Basic Molecular Biology Course in Cardiovascular.
Laboratorium Biomedik. Universitas Brawijaya. Malang.

[17] Luna, G. L. 1968. Manual of histologic staining methods of the armed forces institute of pathology $3^{\text {rd }}$ Edition. McGrawHill Book Company. New york. 158-160.

[18] Santoso. 2000. SPSS statistik parametrik. PT. Elex Media Komputindo. Jakarta.

[19] Sugiyono. 2006. Statistika untuk penelitian. Alfabeta. Bandung.

[20] Ide, T., K. Masayo, T. Yoko, S. Kazuki, F. Nobuhiro, S. Y. Satoko. 2003. Sesamin, a Sesame Lignan, as a potent serum lipidlowering food component. JARQ. 37(3). 151158.

[21] Satchithanandam, S., R. Chanderbhan, A.T. Kharroubi, R. J. Calvert, D. Klurfeld, S. A. Tepper, D. Kritchevsky. 1996. Effect of sesame oil on serum and liver lipid profiles in the rat. Int. J. Vitam. Nutr. Res. 66(4). 386-392.

[22] Ibrahim, W., L. Ung-Soo, Y. Che-C, S. Joseph, B. Geza, K. C. Ching. 1997. Oxidative stress and antioxidant status in mouse liver: effects of dietary lipid, vitamin E and iron. J. Nutr. 127. 1401-1406.

[23] Bonnet, S. G. Rochefort, G. Sutendra, et al. 2007. The nuclear factor of activated T cells in pulmonary arterial hypertension can be therapuetically targeted. Proc. Natl. Acad. Sci. USA. 104(27). 11418-11423.

[24] Azzi, A., B. Isabel, F. Maria, R, Roberta, S. Achim, Z. Sabine, Z. Jean-Marc. 2001. Nonantioxidant Functions of a-Tocopherol in Smooth Muscle Cells. J. Nutr. 131. 378S381S.

[25] Mene, P., S. Michael, Simonson, J. D. Michael. 1989. Physiology of the Mesangial Cell. Am. Physiol. Soc. 69 (4). 1347-1412.

[26] Prigent, C. S., H. Didier, M. Chantal, B. Marie-France, M. Odile, P. Bernard, B. Jean, B. Patrick. 2000. Early glomerular macrophage recruitment in Streptozotocininduced diabetic rats. Diabetes. 49. 466475.

[27] Hristova, E. N., B. H. John. 2001. Metabolic intermediates, inorganic ions and biochemical markers of bone metabolism. In: Clinical diagnosis and management by laboratory $20^{\text {th }}$ Ed. W. B. Saunders company. Phyladelphia. 165-169, 180-183.

[28] Ruan, Z. X. V. Zac, F. M. John. 2003. Inflammation modifies lipid-mediated renal injury. Nephrol. Dial. Transplant. 18. 27-32. 